\title{
Organizational Flexibility and Its Impact on the Service Quality: A Survey Study on Communication and Information Technology Regulatory Authority in Kuwait
}

\author{
Eng. Huda Saad Al Rashidi \\ Ministry of Transportation - State of Kuwait \\ E-mail: alrashidisaod@gmail.com
}

Prof. Dr. Aktham A, AL Sarayreh

AL Balqa Applied University

E-mail: sarah_aktham@yahoo.com

Received: May 16, 2019 Accepted: June 4, 2019 Online published: July 8, 2019

doi:10.5296/ijhrs.v9i3.14797

URL: https://doi.org/10.5296/ijhrs.v9i3.14797

\begin{abstract}
The current study aimes at recognizing the organizational flexibility and its diminsions mainly (strategic strength exercises, practical flexibility, and structural flexibility). Furthermore, it investigates its impact on the service quality in the General Authority for Communications and Information Technology in the State of Kuwait. In order to achieve the objectives of the study, "Descriptive analysis" approach is used by conducting a study in the General Authority for Communications and Information Technology in the State of Kuwait and the results of the current study. The study finds a significant positive impact of organizational fleixibility on the service quality in the General Authority for Communications and Information Technology in the State of Kuwait. The study basically recommends the following procedures: First of all, the General Authority needs for Communication and Technology Information in the State of Kuwait to improve strategic flexibility through the adoption of methods that contribute to improving capabilities and create a competitive advantage, and away from traditional methods. Secondly, the need for the General Authority to improve the operational flexibility by worling hard to make effective changes in the early stages of the activity, which enhances their ability to adapt with the increase in the volume of
\end{abstract}


operations, commensurate with the demand for those services, and the need to be flexible. Finally, this study recommends that the General Authority has to improve the structural flexibility through following an organizational structure capable of dealing with the growing pressure in the operations of the Authority to continue to develop services.

Keywords: organizational fliexability, quality, general authority for communications and information technology

\section{Introduction}

According to the changes in the environment that surrounds the modern organizations with the spread of globalization and the increased innovation at the beginning of the 21 st century. Flexibility "has emerged as one of the key domains of maintaining competitiveness and interoperability among organizations. Today there is complete unanimity about disruptive nature of this ongoing change in business environment though its intensity is different for different sectors of economy. While some of industries aren't much affected by change; there are some like the Service sector, which has got short end of this dynamism support. (Shalender, 2015).

Al-Anizi et., al (2013) have noted that Organizational Flexibility core is represented by the ability of the organization to mobilize and adapt its resources towards rapid adaptation and response to sudden and unexpected events.. Therefore, the best solution for maintaining stability, sustainability, and even the success of the organization in its activity relies in the organizational flexibility, which is represented by different forms such as: production, processing, service, workforce, speed, technology and organizational structure (Heng 2010). Organizational flexibility also has a positive impact on the organization. It contributes to increased profitability, customer satisfaction, increases product and service quality, productivity, improves level of the innovation, reduces the indiviusals effort throughthe integrated work, and provides a suitable environment for its employees (Zaidi et ., al 2016).

Organizational flexibility is future-orientedadministrative team's strategic vision is reflected by the decision makers, which must show same involvement in current organizational issues, as well as in newprojects. The upgrading levelof the quality inthe institutional services which leds to the improvement of its activities (Cornescu et al., 2012). The word Service itself " refers to any act or performance performed by a person or organization to another team in an intangible manner, as it does not result in material ownership often, and its production is linked to normal production by a prior request from the latter team, the service is immaterial in nature, Constantly changing, non-storageable, as they are non-separable or fragmented (Al-Bakri, 2010), and (Al-Saman,2016). Thus, the quality of the service provided to customers and the endusers has to meet their expectations and needs, which achieve a competitive advantage for the organization withdistinction in the level of the service (Al-Wadi et al., 2010).

\section{Statement of the Problem}

Accurate measurement of the service quality can only be carried out by studying the viewpoint of the beneficiaries. Measuring the level of service quality needs to determine the 
trends and objectives of senior management in the organization and to reach the level of "Superiority of service" that represented by the expected service for the customers Bou (Abdullah, 2010). (Altman, 1985) summs up the five dimensions for measuring level of quality of the sevice provided to the customers in his model, which are the tangibility, reliability, responsiveness, assurance, and empathy (Mohammad, 2011). In order to achieve high level of excellence considering the service quality, the management of the organization has to apply the dimensions of organizational flexibility to meet the customer's satisfaction. (Weerdt et., al, 2012) have however stated a range of organizational flexibility dimensions that have been applied to a wide range of institutions and studies, namely, the strategic flexibility, the operational flexibility, and structural flexibility. The problem of this very study lies in identifying the Impact of Organizational Flexibility on the Service quality in Communication and Information Technology Regulatory Authority.

The problem of the current study aims to investigate the answer of the stated question of the impact of Organizational Flexibility on the Service quality that providedby Communication and Information Technology Regulatory Authority in Kuwait from the viewpoint of its employees.

\section{Objectives of the Study}

This study aims to identify the impact of Organizational Flexibility on the Service quality provided by Communication and Information Technology Regulatory Authority in Kuwait.

\section{The Study Model}

Figure (1) represents the model of this study which shows the relationship between the independent and dependent variables of the study:
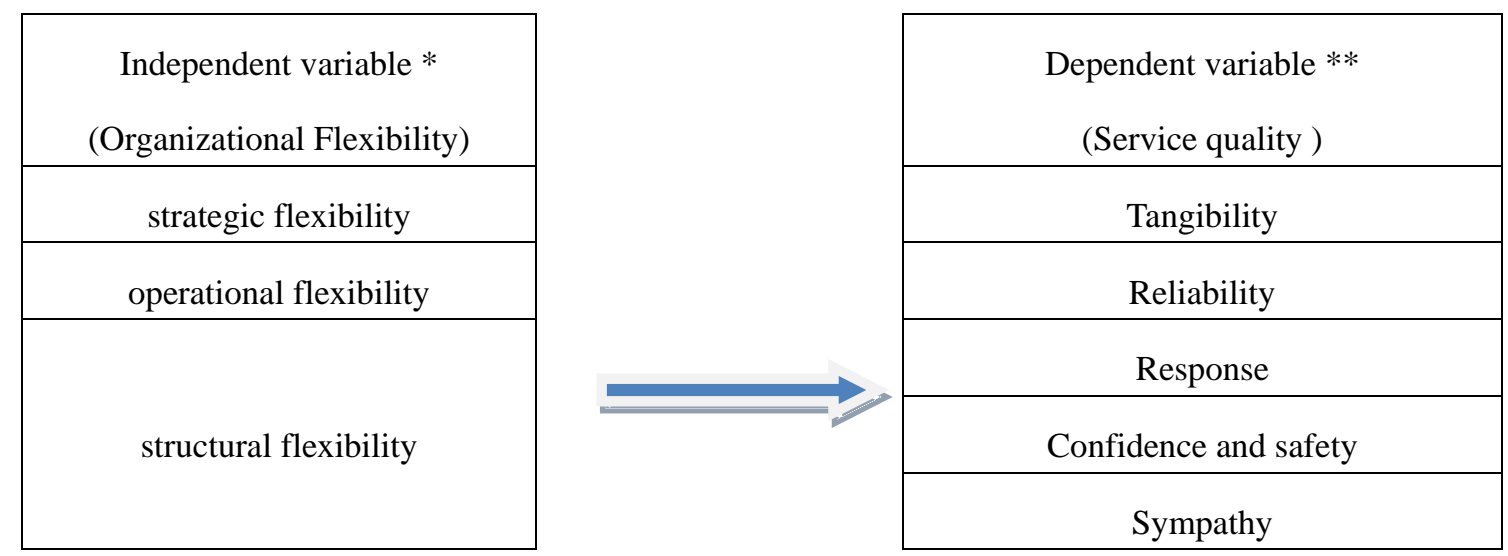

\section{Hypotheses of the Study}

Based on the study problem, the researcher formulates the following major hypothesis:

5-1.The impact of organizational flexibility in its dimensions (strategic flexibility, operational flexibility, structural flexibility) on the service quality provided by the General Authority for Communications and Information Technology in the State of Kuwait.

The main hypothesis is divided from the following sub-hypotheses: 
H01a: There is an impact for the organizational flexibility of its dimensions (strategic flexibility, operational flexibility, structural flexibility) on the level of tangible service quality provided by the General Authority for Communications and Information Technology in the State of Kuwait.

H01b: There is an impact for the organizational flexibility of its dimensions (strategic flexibility, operational flexibility, structural flexibility) on the level of reliability in the service quality provided by the General Authority for Communications and Information Technology in the State of Kuwait

H01c: There is an impact for the organizational flexibility of its dimensions (strategic flexibility, operational flexibility, structural flexibility) on the service quality response provided by the General Authority for Communications and Information Technology in the State of Kuwait.

H01d: There is an impact for the organizational flexibility of its dimensions (strategic flexibility, operational flexibility, structural flexibility) on the level of confidence and safety in the service quality provided by the General Authority for Communications and Information Technology in the State of Kuwait.

H01e: There is an impact for the organizational flexibility of its dimensions (strategic flexibility, operational flexibility, structural flexibility) on the level of sympathy in service quality provided by the General Authority for Communications and Information Technology in the State of Kuwait.

\section{The Concept of Organizational Flexibility}

By doing a review of literature related to the subject of the study, the researcher found a set of important definitions of the concept of organizational flexibility as follows:

Al Fadel (2015) and Madhani (2013) have defined it as "the ability to deal with uncertainties and changes in the business environment". (Al-Anizi et., al 2013) and, (Idrees 2016) define it as "the ability of the Organization to mobilize and adapt its resources to the speed of adaptation and response to the sudden and unexpected events". Organizational flexibility is the main capability that enables organizations to face environmental fluctuations, as it makes them more responsive to change. Organizational flexibility, particularly strategic one, directs operation of the organization, conditioning decisively its long-term performance (Cornescu et., al. 2012), and (Al-Tit 2016) Organizational flexibility is need of organization to develop and prevail different types of dynamic capabilities that result in first-class changes in the organization and processes to deal with demand variability, but in particular the highest capacity to quickly reconfigure its resources (Weerdt, 2009).

\subsection{The Importance of Organizational Flexibility}

The recent changes make the organizations more interactive with the environment which require greater efforts in the planning procedure and manage its resources. This requires that the organization be highly flexible and decentralized while maintaining its management competencies at a high level, with the availability of human resources who have creative 
capabilities, desire for change and development (Al-Sarayreh et., al. 2010). (Zaidi et., al. 2016) point out that organizational flexibility contributes to improving a number of factors, including profitability, customer satisfaction and loyalty, quality of work and product, professionalism, productivity, innovation, teamwork and the creation of an appropriate environment for the work.

\subsection{Organizational Flexibility Variables}

Li, et., al (2008) and, (Boyabatli, et.,al 2017), have set the most important variables that are related to a flexible organization which can be summarized as follow:

Organizational Culture: Can be portrayed as the set of beliefs and assumptions held commonly throughout the organization and taken for granted by its members.

Competitive Advantage: Change in the competitive advantage of the Organization according to the available resources, as appropriate with the changes in the internal and external eniveronment.

Organizational Knowledge: When the organization reaches to the level of the educated organization and has specialization in its activities, which makes it able to raise the efficiency of employees.

Research and Development Resources: Through the identification of methods for the preparation of future studies and diagnostics, plans, programs, and the organization of the record of production capacity and studies aim at investigating the optimal use of resources in the production and processing.

Human resources: Human resources are essential because they have inexhaustible, creative, developmental and potential ability, with the capacity to adequately produce and combine all the other categories of organization's resources. In such context, human resources must be structured on two coordinates - quantitative and qualitative. The quantity coordinate of analysis refers to adequate dimensioning of personnel effective, while the quality coordinate concerns a series of aspects, such as the structural evaluation of human resources.

Commercial Resources: Commercial resources consist of marketing activities, technical-material, and sales supplies. Marketing activity analysis includes internal market prospect, of external market (in the case in which organization is integrated in the system of international economical relations) and is finalized by suggesting ways of product sales growth.

Financial Resources: Financial analysis resources aim at evaluating circulatory assets on the point of view of structure and volume, of cash flow and relations with banks. Financial resources have significant impact on economic force of organization on what concerns market competition, thus it imposes their rational use, especially nowadays, marked by major financial constraint.

\subsection{Organizational Flexibility Dimensions}

Weerdt et al. (2012), and (Li et., al 2008) have set dimensions of the organizational flexibility, 
the most important dimension is the Strategic Flexibility which includes the management techniques that used to create a set of organizational capabilities which stemming from strategic options that implemented at a relatively high level of changes as follows:

Resources Flexibility: The ability of organizations to deal with their total financial, material, human, knowledge, and skills assets which give the organization the ability to activate strategic options through different management systems.

Capability Flexibility: It represents the ability of organizations to make full use of the available resources to meet the needs and expectations of the customers and achieve competitive advantage.

Operational Flexibility: Operational flexibility provides rapid response to changes that are familiar and typically leads to temporary fluctuations in the firm's activity. The objective of operational flexibility is to maximize efficiency in the operational activities.

Functional Flexibility: It is the ability of the organization to change the type of work that uses without using the external labor market. This can achieved through the design of functions and tasks capable of containing a wide range of tasks and this gives the employees the ability to move from one task to another.

Numerical Flexibility: The numerical or "internal" flexibility reflects the organization's ability to change the number of employees or distribution of working hours over a given period of time. This flexibility can be achieved through changes in working hours without recourse to the external market.

Structural Flexibility: The ability to direct the system's capabilities is within the administrative framework or in the company's resources and competencies. Structural flexibility consists of managerial capabilities to adapt the organizational structure, decision-making processes and communication to suit with the changing circumstances in a modern way.

Structural flexibility involves changing the routine procedures that directed the company's management framework, such as organizational structure, decision-making routine, or communication processes between the various management levels in the organizational structure. Organizational structures however can be classified as follows:

Mechanistic Structure: Mechanistic structures are characterized by highly regulated processes and elaborate planning and control systems, specialization of tasks, and high degrees of formalization and centralization.

Organic Structure: Organic structures, on the other hand, are characterized by a basic organization form that can deal with increased coordination needs between interfacing units, a rudimentary performance-oriented planning and control system that allows for ambiguous information and necessary experimentation 


\section{Service Quality}

\subsection{The concept of Service Quality}

There are many definitions for the concept of service quality varied according to their fields. The most important definitions are: The service quality s depends on organizational resources which is not being taxable like the quality of goods. (Hartwig et., al. 2018), defined it as "The degree of the actual performance of the service that matches with customer expectations for the service. Therefore, the quality of the service is defined as the level of performance in the provided service compared to the level of the customers expectetions which the organization seeks to access and it is considered as a main priority of it`s activity (Al-Sarayreh, et.,al 2016).

\subsection{The Importance of Service Quality}

Service quality is important for organizations. It represents a competitive advantage and a strategic goal for organizations by resorting to develop the process and redesign it in order to increase the effectiveness of its services and improve the satisfaction of its customers. This makes the quality as part of the culture of organizations (Dulaimi, 2005).

\subsection{Service Quality Dimensions}

Mohammed (2011) summarizes the basic dimensions of Service quality as identified by Altman:

Tangibility: The appearance of physical facilities, equipment, personal appearance, and communication materials.

Reliability: The ability to perform the promised service dependably and accurately.

Response: The willingness to help customers and provide prompt serviceThe ability to perform the promised service dependably and accurately.

Trust and Safety: Creating and gaining confidence. Trust is generally an important and successfulpart for making relationships. It represents the willingness and readiness of the other team to make trade exchange.

Sympathy: The level of care and personal attention that given to the customer or the client. It is well known that the client who receives a good service becomes has loyality to the organization that provides this service through a transaction that reflects knowledge of its requirements and needs.

\section{Design and Methodology}

This study follows descriptive analysis to define the organizational flexibility its impact on the level of service quality in the General Authority for Administration and Information Technology in the State of Kuwait.

\subsection{The Target of the Study}

The target of the study includs all the employees of the General Authority for 


\section{Macrothink}

International Journal of Human Resource Studies

ISSN 2162-3058 2019, Vol. 9, No. 3

Communications and Information Technology in the year 2019, which is 350 employees, which provides technological services because it is one of the most active and developed sector in Kuwait, as well as being the most affected by technological developments and technical fluctuations.

\subsection{The Sample of Study}

The sample of the study included all employees of the public service in the General Authority for Communications and Information Technology - the State of Kuwait which are (60) employees, considering that these departments are one of the most departments concerned with the service quality .

\section{Data Analysis and Hypothesis Testing}

\subsection{Results Related to the Main Hypothesis}

To test this hypothesis, the multiple regression analysis is employed to measure the effect of the independent variable (organizational flexibility) in terms of its three dimensions (strategic flexibility, operational flexibility, structural flexibility) on the dependent variable (Service quality) as a whole. The validity of the model for this hypothesis was confirmed by extracting the results of the regression analysis as shown in Table (1)

Table (1). Results of (analysis of variance) to verify the validity of the model to test the main hypothesis

\begin{tabular}{l|l|l|l|l|l|l|l}
\hline $\begin{array}{c}\text { Source } \\
\text { variance }\end{array}$ & $\begin{array}{c}\text { Total } \\
\text { squares }\end{array}$ & $\begin{array}{c}\text { Freedo } \\
\mathbf{m} \\
\text { Degrees }\end{array}$ & $\begin{array}{c}\text { Average } \\
\text { squares }\end{array}$ & F & Sig & $\begin{array}{c}\text { Coefficient } \\
\text { of } \\
\text { correlation }\end{array}$ & $\mathbf{R}^{\mathbf{2}}$ \\
\cline { 1 - 3 } Regression & 14.005 & 3 & 4.668 & \multirow{2}{*}{36.855} & $* 0.000$ & 0.815 & \multirow{2}{*}{0.664} \\
\cline { 1 - 4 } The error & 7.093 & 56 & 0.127 & & & & \\
\hline
\end{tabular}

Table (1) shows the validity ofthe test model for the main hypothesis. The calculated value of $(F)$ of the model was (36.855), which is a statistical significance at the level of significance ( $\alpha$ $\leq 0.05)$. The value of the (R2) $(66.4 \%)$ This means that independent variables in the model are interpreted $(66.4 \%)$ (Service quality as a whole).

Table (2) shows the results of the main hypothesis test using multiple regression analysis

Table (2). Results of the multiple regression analysis to test the impact of organizational flexibility in terms of its three dimensions, at the level of service quality provided by the General Authority for Communications and Information Technology

\begin{tabular}{l|l|l|l|l|l}
\hline $\begin{array}{l}\text { Independent variable } \\
\text { (Organizational flexibility) }\end{array}$ & $\begin{array}{l}\text { B } \\
\text { Value }\end{array}$ & $\begin{array}{l}\text { Standard } \\
\text { error }\end{array}$ & Beta & $\begin{array}{l}\text { T } \\
\text { value }\end{array}$ & sig \\
\hline (Constant) & 1.271 & 0.244 & & 5.213 & 0.000 \\
\hline Strategic flexibility & 0.169 & 0.106 & 0.204 & 1.595 & 0.116 \\
\hline Operational flexibility & 0.308 & 0.129 & 0.348 & 2.379 & $* 0.021$ \\
\hline
\end{tabular}




\begin{tabular}{l|l|l|l|l|l}
\hline $\begin{array}{l}\text { Independent variable } \\
\text { (Organizational flexibility) }\end{array}$ & $\begin{array}{l}\text { B } \\
\text { Value }\end{array}$ & $\begin{array}{l}\text { Standard } \\
\text { error }\end{array}$ & Beta & $\begin{array}{l}\text { T } \\
\text { value }\end{array}$ & sig \\
\hline Structural flexibility & 0.283 & 0.101 & 0.340 & 2.807 & $* 0.007$ \\
\hline
\end{tabular}

The dependent variable (the Service quality as a whole).

Table 2 shows that the most effective organizational flexibility dimension in the service quality as a whole is operational flexibility, the value of $(\mathrm{t})$ calculated (2.379) and the value (Beta) (0.348) Which are significant values at $(\alpha \leq 0.05)$ and by the value of (B) "impact size" which is (0.308) and indicates the improvement in the dependent variable (Service quality as a whole). As a result of the increase in operational flexibility we conclude that increasing the operational flexibility of the value of one unit leads to an improvement in the service quality provided by the General Authority for Communications and Information Technology by (30.8\%) of this unit, followed by the effect of structural flexibility dimension, where the value of $(t)$ calculated (2.807) and the value (Beta) (0.340), which are values of statistical significance at the level of $(\alpha \leq 0.05)$, from the value of $(B)$ which is $(0.283)$ we conclude that the increase in structural flexibility one unit leading to an improvement in the service quality that provided by the General Authority for Telecommunications and information technology by (28.3\%) from this unit.

While the results in the previous table indicate that the strategic flexibility does not affect the service quality provided by the General Authority for Communications and Information Technology, the values of ( $t$ ) and (Beta) of this dimension did not reach the level of significance $(\alpha \leq 0.05)$.

The previous results entail that the main hypothesis is rejected in part, as follows: There is a significant positive effect at the level of $(\alpha \leq 0.05)$ of the organizational flexibility of the dimension (operational flexibility, structural flexibility) in the service quality provided by the General Authority for Communications and Information Technology Kuwait, while there is no significant effect at the level of $(\alpha \leq 0.05)$ for the strategic flexibility in the service quality provided by the General Authority for Communications and Information Technology in the State of Kuwait .

\subsection{Results Related to the First Sub-Hypothesis}

To test this hypothesis, the multiple regression analysis is used to measure the effect of the independent variable (organizational flexibility) in terms of its three dimensions (strategic flexibility, operational flexibility, structural flexibility) on the dependent variable (The level of tangibility). The validity of the model for this hypothesis was confirmed by extracting the results of the regression analysis as shown in Table (3): 
Table (3). Results of regression (Analysis of Variance) to validate the validity of the model to test the first hypothesis

\begin{tabular}{l|l|l|l|l|l|l|l}
\hline $\begin{array}{c}\text { Source } \\
\text { variance }\end{array}$ & $\begin{array}{c}\text { Total } \\
\text { squares }\end{array}$ & $\begin{array}{c}\text { Freedom } \\
\text { Degrees }\end{array}$ & $\begin{array}{c}\text { Average } \\
\text { squares }\end{array}$ & $\begin{array}{c}\text { F } \\
\text { Value }\end{array}$ & Sig & $\begin{array}{c}\text { Coefficient of } \\
\text { correlation }\end{array}$ & $\mathbf{R}^{2}$ \\
\cline { 1 - 4 } $\begin{array}{l}\text { Regressio } \\
\mathbf{n}\end{array}$ & 12.648 & 3 & 4.216 & 11.755 & $\begin{array}{l}0.00 \\
* 0\end{array}$ & 0.622 & $\begin{array}{l}0.3 \\
86\end{array}$ \\
\cline { 1 - 4 } The error & 20.084 & 56 & 0.359 & & & & \\
\cline { 1 - 5 } Total & 32.732 & 59 & & & & & \\
\hline
\end{tabular}

$* \alpha$ (significance level $\leq \mathbf{0 . 0 5})$

Table (3) shows the validity of the first sub-hypothesis test model, with the calculated value of (F) of the model (11.755), which is a significance at the level of $(\alpha \leq 0.05)$, and the value of the R2 (0.386) Means that the independent variables in the model explained $38.6 \%$ of the variance in the dependent variable (the significant level of service qualitytangibility). Table (4) shows the results of the first sub-hypothesis test using multiple regression analysis:

Table (4). Results of the multiple regression analysis are to test the impact of organizational flexibility in terms of its three dimensions, at the leveltangibility of service quality provided by the General Authority for Communications and Information Technology

\begin{tabular}{l|l|l|l|l|l}
\hline $\begin{array}{c}\text { Independent variable } \\
\text { (Organizational flexibility) }\end{array}$ & $\begin{array}{c}\text { B } \\
\text { Value }\end{array}$ & $\begin{array}{c}\text { Standard } \\
\text { error }\end{array}$ & Beta & T value & sig \\
\hline (Constant) & 1.518 & 0.410 & & 3.699 & 0.000 \\
\hline Strategic flexibility & 0.145 & 0.179 & 0.140 & 0.810 & 0.422 \\
\hline Operational flexibility & 0.132 & 0.218 & 0.120 & 0.608 & 0.546 \\
\hline Structural flexibility & 0.430 & 0.170 & 0.415 & 2.534 & $* 0.014$ \\
\hline
\end{tabular}

The dependent variable (the level of service quality)

The results in table (4) show that structural flexibility is the most influential factor in the quality level of the service. The calculated value of $t$ (2.534) and Beta (0.415) are significant at $(\alpha \leq 0.05)$, and by the value of "B" (0.430), Impact Size, It indicates the improvement in the dependent variable (the tangibility) as a result of the increase in structural flexibility,we conclude that increasing the structural flexibility with the value of one unit leads to an improvement in the tangible service quality provided by the General Authority for Communications and Information Technology by (43\%) of this unit. While the results in the previous table indicates that strategic flexibility and operational flexibility do not affect the level of tangible service quality which is provided by the General Authority for Communications and Information Technology. The values of (t) and (Beta) for these two dimensions haven't reached the specified level of significance $(\alpha \leq 0.05)$.

From the previous results, the first sub-hypothesis is rejected in part, as follows: There is a significant positive effect at the level of $(\alpha \leq 0.05)$ of the structural flexibility at the level of tangible service quality provided by the General Authority for Communications and 
Information Technology in the State of Kuwait, while there is no significant impact at the level of $(\alpha \leq 0.05)$ for the strategic flexibility and operational flexibility at the level of tangible service quality provided by the General Authority for Communications and Information Technology in the State of Kuwait.

\subsection{Results Related to the Second Sub-Hypothesis}

To test this hypothesis, the multiple regression analysis was used to measure the effect of the independent variable (organizational flexibility) in terms of its three dimensions (strategic flexibility, operational flexibility, structural flexibility) on the dependent variable (Service quality reliability). The validity of the model for this hypothesis was verified by extracting the results of the regression analysis as shown in Table 5:

Table (5). Results of (analysis of variance) to verify the validity of the model to test the second hypothesis

\begin{tabular}{|c|c|c|c|c|c|c|c|}
\hline $\begin{array}{c}\text { Source } \\
\text { Variance }\end{array}$ & $\begin{array}{c}\text { Total } \\
\text { squares }\end{array}$ & $\begin{array}{c}\text { Freedo } \\
\text { m } \\
\text { Degrees }\end{array}$ & $\begin{array}{c}\text { Avera } \\
\text { ge } \\
\text { square } \\
\text { s } \\
\end{array}$ & $\begin{array}{c}\mathbf{F} \\
\text { Value }\end{array}$ & Sig & $\begin{array}{c}\text { Coefficient } \\
\text { of } \\
\text { correlation }\end{array}$ & $\begin{array}{c}\mathbf{R}^{2} \\
\text { Value }\end{array}$ \\
\hline Regression & 11.484 & 3 & 3.828 & \multirow[t]{3}{*}{11.374} & \multirow{3}{*}{$\begin{array}{l}0.000 \\
*\end{array}$} & \multirow[t]{3}{*}{0.615} & \multirow[t]{3}{*}{0.379} \\
\hline The error & 18.847 & 56 & 0.337 & & & & \\
\hline The total & 30.331 & 59 & & & & & \\
\hline
\end{tabular}

* $(\alpha \leq \mathbf{0 . 0 5})$ significance level

Table (5) shows the validity of the model for the second hypothesis; the calculated value of (F) for the model is (11.374), which is a value at the level of significance $(\alpha \leq 0.05)$. The value of (R2) (0.379) means that the independent variables in the model account for $(37.9 \%)$ of the variance in the dependent variable (the reliability level onservice quality). Table 6 shows the results of the second sub-hypothesis test using multiple regression analysis:

Table (6). Results of multiple regression analysis to analyze the impact of organizational flexibility in terms of its three dimensions, on the level of reliability in the service quality provided by the General Authority for Communications and Information Technology

\begin{tabular}{l|l|l|l|l|l}
\hline $\begin{array}{c}\text { Independent variable } \\
\text { (Organizational flexibility) }\end{array}$ & $\begin{array}{c}\text { B } \\
\text { Value }\end{array}$ & $\begin{array}{c}\text { Standard } \\
\text { error }\end{array}$ & Beta & T value & sig \\
\hline (Constant) & 1.811 & 0.397 & & 4.558 & 0.000 \\
\hline Strategic flexibility & 0.036 & 0.173 & 0.037 & 0.210 & 0.834 \\
\hline Operational flexibility & 0.489 & 0.211 & 0.462 & 2.321 & $* 0.024$ \\
\hline Structural flexibility & 0.151 & 0.164 & 0.152 & 0.921 & 0.361 \\
\hline
\end{tabular}

Dependent variable (reliability level of Service quality)

The results in Table (6) show that the operational flexibility is the most influential factor in the level of reliability of the service quality. The calculated value of $(t)(2.321)$ and the value of (Beta) (0.462) are values of significance at the level of significance $(\alpha \leq 0.05)$ and through 
the value of (B) "impact size" of (0.489)which indicates the improvement in the dependent variable (reliability level onservice quality ) as a result of the increase in operational flexibility, we conclude that the increase in the operational flexibility for one unit leads to an improvement in the reliability of the service quality provided by the General Authority for Communications and Information Technology by(48.9\%) from this unit.

The results in the previous table indicate that strategic flexibility and structural flexibility do not affect the service quality reliability provided by the General Authority for Communications and Information Technology. The values of (t) and (Beta) for these two dimensions did not reach the level of significance $(\alpha \leq 0.05)$.

By looking at the previous results, the second sub-hypothesis is rejected in part, as follows: There is a significant positive effect at the level of $(\alpha \leq 0.05)$ for the operational flexibility in the service quality provided by the General Authority for Communications and Information Technology in the State of Kuwait, While there is no statistically significant effect at the level of $(\alpha \leq 0.05)$ significance of the strategic flexibility and structural flexibility in the level of reliability on the provided by the General Authority for Communications and Information Technology in the State of Kuwait.

\subsection{Results Related to the Third Sub-Hypothesis}

To examine this hypothesis, the multiple regression analysis is applied to measure the effect of the independent variable (organizational flexibility) in terms of its three dimensions (strategic flexibility, operational flexibility, structural flexibility) on the dependent variable (Service quality). The validity of the model for this hypothesis was verified by extracting the results of the regression analysis as shown in Table (7)

Table (7). Results of (analysis of variance) to confirm the validity of the model to test the third hypothesis

\begin{tabular}{|c|c|c|c|c|c|c|c|}
\hline $\begin{array}{c}\text { Source } \\
\text { Of } \\
\text { variaance }\end{array}$ & $\begin{array}{c}\text { Total } \\
\text { squares }\end{array}$ & $\begin{array}{c}\text { Freedo } \\
\text { m } \\
\text { Degrees }\end{array}$ & $\begin{array}{l}\text { Average } \\
\text { squares }\end{array}$ & $\begin{array}{c}\mathbf{F} \\
\text { Value }\end{array}$ & Sig & $\begin{array}{l}\text { Coefficient } \\
\text { of } \\
\text { correlation }\end{array}$ & $\mathbf{R}^{2}$ \\
\hline $\begin{array}{l}\text { Regressio } \\
\text { n }\end{array}$ & 15.180 & 3 & 5.060 & \multirow[t]{3}{*}{18.983} & \multirow[t]{3}{*}{$* 0.000$} & \multirow[t]{3}{*}{0.710} & \multirow[t]{3}{*}{0.504} \\
\hline The erorr & 14.927 & 56 & 0.267 & & & & \\
\hline The total & 30.106 & 59 & & & & & \\
\hline
\end{tabular}

$*(\alpha \leq 0.05)$ significance level.

Table (7) shows the validity of the third sub-hypothesis test model, with the calculated value of $(\mathrm{F})$ of the model (18.983), which is statistically significant value at the level of significance $(\alpha \leq 0.05)$. The value of the R2 (0.504). This means that independent variables in the model explained $50.4 \%$ of the variance in the dependent variable (Service quality). Table (8) shows the results of the third sub-hypothesis test using multiple regression analysis. 


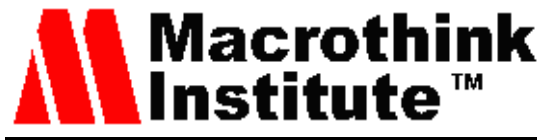

Table (8). Results of multiple regression analysis to test the impact of organizational flexibility in terms of its three dimensions, on the level of service quality response provided by the General Authority for Communications and Information Technology

\begin{tabular}{l|l|l|l|l|l}
\hline $\begin{array}{c}\text { Independent variable } \\
\text { (Organizational flexibility) }\end{array}$ & B & \multicolumn{1}{c|}{$\begin{array}{c}\text { standard } \\
\text { error }\end{array}$} & Beta & T & sig \\
\hline (Constant) & 1.256 & 0.354 & & 3.553 & 0.001 \\
\hline Strategic flexibility & 0.169 & 0.154 & 0.170 & 1.097 & 0.277 \\
\hline Operational flexibility & 0.390 & 0.188 & 0.370 & 2.080 & $* 0.042$ \\
\hline Structural flexibility & 0.232 & 0.146 & 0.234 & 1.586 & 0.118 \\
\hline
\end{tabular}

Dependent variable (Service quality response level)

The results in Table (8) indicate that operational flexibility is the most influential factor in the service quality response. The calculated $(\mathrm{t})$ value of (2.080) and the (Beta) value $(0.370)$ indicate the improvement in the dependent variable (Service quality) as a result of the increase in operational flexibility. Therefore we conclude that increasing the operational flexibility of one unit leads to an improvement in the service quality response provided by the General Authority for Communications and Information Technology (ICT) by (39.0\%) of this unit.

The results from the previous table to the strategic flexibility and structural flexibility do not affect the level of response to the service quality provided by the General Authority for Communications and Information Technology. The values of (t) and (Beta) for these two dimensions haven't reached the specified level of significance $(\alpha \leq 0.05)$. By looking at the previous results, the third sub-hypothesis is rejected in part, as follows:There is a significant positive effect at the level of $(\alpha \leq 0.05)$ of the operational flexibility of the response level in the service quality provided by the General Authority for Communications and Information Technology in the State of Kuwait, While there is no significant effect at the level of $(\alpha \leq$ 0.05)for the strategic flexibility and structural flexibility at the level of response to the service quality that provided by the General Authority for Communications and Information Technology in the State of Kuwait.

\subsection{Results Related to the Fourth Sub-Hypothesis}

To test this hypothesis, the multiple regression analysis was used to measure the effect of the independent variable (organizational flexibility) in terms of its three dimensions (strategic flexibility, operational flexibility, structural flexibility) on the dependent variable (confidence level and safety on service quality). The validity of the model for this hypothesis was confirmed by extracting the results of the regression analysis as shown in Table (9) 
Table (9). Results of (analysis of variance) to verify the validity of the model to test the foth hypothesis

\begin{tabular}{l|l|l|l|l|l|l|l}
\hline \multicolumn{1}{c|}{$\begin{array}{c}\text { Source } \\
\text { Variance }\end{array}$} & $\begin{array}{c}\text { Total } \\
\text { squares }\end{array}$ & $\begin{array}{c}\text { Freedom } \\
\text { Degrees }\end{array}$ & $\begin{array}{c}\text { Average } \\
\text { squares }\end{array}$ & $\mathbf{F}$ & \multicolumn{1}{|c|}{ sig } & $\begin{array}{c}\text { Coefficient of } \\
\text { correlation }\end{array}$ & $\mathbf{R}^{2}$ \\
\hline Regression & 17.892 & 3 & 5.964 & 29. & $* 0.000$ & 0.784 & 0.614 \\
\hline The error & 11.241 & 56 & 0.201 & 71 & & & \\
\hline The total & 29.133 & 59 & & 1 & & & \\
\hline
\end{tabular}

$*(\leq \mathbf{0 . 0 5} \alpha)$ significance level

Table (9) shows the validity of the fourth hypothesis test model. The calculated value of (F) of the model $(29,711)$ is statistically significant value at the level of significance $(\alpha \leq 0.05)$. The value of the R2 (0.614) means that the independent variables in the model account for $(61.4 \%)$ of the variance in the dependent variable (the level of confidence and safety in the service quality). Table (10) shows the results of the fourth hypothesis test using multiple regression analysis:

Table (10). Results of Multiple Regression Analysis to Examine the Effect of Regulatory Flexibility in terms of its Three Dimensions, on level of Confidence and Safety on service quality provided by the General Authority for Communications and Information Technology

\begin{tabular}{l|l|l|l|l|l}
\hline $\begin{array}{c}\text { Independent variable } \\
\text { (Organizational flexibility) }\end{array}$ & B & $\begin{array}{c}\text { standard } \\
\text { error }\end{array}$ & Beta & t & sig \\
\hline (Constant) & 0.827 & 0.307 & & 2.693 & 0.009 \\
\hline Strategic flexibility & 0.171 & 0.134 & 0.175 & 1.277 & 0.207 \\
\hline Operational flexibility & 0.389 & 0.163 & 0.375 & 2.388 & $* 0.020$ \\
\hline Structural flexibility & 0.299 & 0.127 & 0.306 & 2.358 & $* 0.022$ \\
\hline
\end{tabular}

Dependent variable (confidence level and security on service quality)

Table (10) shows that the most effective organizational flexibility considering the service quality was operational flexibility, with a calculated value of $t$ (2.388) and a value of (Beta) (0.375), which are significant at the significance level $(\alpha \leq 0.05)$, and by the value of (B) the "impact size" of (0.389) it indicates that the improvement in the dependent variable (confidence level and safety on service quality ) due to the increase in operational flexibility, we conclude that the increase in the operational flexibility of the value of one unit leads to an improvement in the level of confidence and safety in the service quality provided by the General Authority for Communications and Information Technology (38.9\% \%) Of this unit.Followed by the effect of the structural flexibility, where the value of (t) calculated (2.358) and the value of (Beta) (0.306), which are values of statistical significance at the level $(\alpha \leq 0.05)$ and from the value of (B) of (0.299) we conclude that the increase in the structural flexibility value of one unit leads to an improvement in the level of confidence and safety in the service quality provided by the General Authority for Communication and Information Technology (29.9\%) of this unit.

While the results in the previous table indicate that the strategic flexibility does not affect the 


\section{Macrothink}

International Journal of Human Resource Studies

ISSN 2162-3058

2019, Vol. 9, No. 3

level of confidence and safety in the service quality provided by the General Authority for Communications and Information Technology since the values of ( $t$ ) and (Beta) of this dimension haven't reached the level of significance $(\alpha \leq 0.05)$.

In light of the previous results, the fourth sub-hypothesis is rejected in part, as follows: There is a statistically significant positive effect at the level of $(\alpha \leq 0.05)$ of the operational flexibility and structural flexibility in the level of confidence and safety in the service quality provided by the General Authority for Communications and Information Technology in the State of Kuwait, while there is no statistically significant effect at the level of $(\alpha \leq 0.05)$ for the strategic flexibility in the level of confidence and safety in the service quality provided by the General Authority for Communications and Information Technology in the State of Kuwait.

\subsection{Results Related to the Fifth Sub-Hypothesis}

To test this hypothesis, the multiple regression analysis was used to measure the effect of the independent variable (organizationalflexibility) in terms of its three dimensions (strategic flexibility, operational flexibility, structural flexibility) on the dependent variable (level of sympathy for Service quality). The validity of the model for this hypothesis was confirmed by extracting the results of the regression analysis as shown in Table (11).

Table (11). Results of (analysis of variance) to verify the validity of the model to test the fifth hypothesis

\begin{tabular}{l|l|l|l|l|l|l|l}
\hline \multicolumn{1}{c|}{$\begin{array}{c}\text { Total } \\
\text { squares }\end{array}$} & $\begin{array}{c}\text { Average } \\
\text { squares }\end{array}$ & $\begin{array}{c}\text { Freedom } \\
\text { Degrees }\end{array}$ & $\begin{array}{c}\text { Average } \\
\text { squares }\end{array}$ & $\mathbf{F}$ & sig & $\begin{array}{c}\text { Coefficient of } \\
\text { correlation }\end{array}$ & $\mathbf{R}^{\mathbf{2}}$ \\
\hline Variance & 14.448 & 3 & 4.816 & 17.2 & $* 0.000$ & 0.693 & 0.480 \\
\cline { 1 - 3 } $\begin{array}{l}\text { The } \\
\text { error }\end{array}$ & 15.632 & 56 & 0.279 & 53 & & & \\
\hline The total & 30.08 & 59 & & & & & \\
\hline
\end{tabular}

$*(\alpha \geq 0.05)$ significance level

Table (11) shows the validity of the fifth sub-hypothesis test model. The calculated value of (F) of the model (17.253) is statistically significant value at the level of $(\alpha \leq 0.05)$. The value of the (R2) was (0.480) which means that the independent variables in the model account for $48 \%$ of the variation in the dependent variable (the level of sympathy for service quality). Table (12) shows the results of the fifth sub-hypothesis test using multiple regression analysis: 
Table (12). Results of Multiple Regression Analysis to Examine the Effect of Organizational Flexibility by the Three Dimensions on the Level of Sympathy in the Service quality provided by the General Authority for Communications and Information Technology

\begin{tabular}{l|l|l|l|l|l}
\hline $\begin{array}{c}\text { Independent variable } \\
\text { (Organizational flexibility) }\end{array}$ & \multicolumn{1}{|c|}{$\mathrm{B}$} & \multicolumn{1}{c|}{$\begin{array}{c}\text { standard } \\
\text { error }\end{array}$} & Beta & $\begin{array}{c}\mathrm{T} \\
\text { value }\end{array}$ & \multicolumn{1}{c}{ sig } \\
\hline (Constant) & 0.941 & 0.362 & & 2.599 & 0.012 \\
\hline Strategic flexibility & 0.326 & 0.158 & 0.328 & 2.067 & $* 0.043$ \\
\hline Operational flexibility & 0.137 & 0.192 & 0.130 & 0.716 & 0.477 \\
\hline Structural flexibility & 0.303 & 0.150 & 0.306 & 2.027 & $* 0.047$ \\
\hline
\end{tabular}

Dependent variable (level of sympathy for Service quality)

Table (30) shows that the most significant organizational flexibility in the service quality as a whole follows the strategic flexibility. The calculated value of $\mathrm{T}(2.067)$ and Beta (0.328) are statistically significant at the significance level $(\alpha \leq 0.05)$, and by the value of $(B)$ the "impact size" of (0.326) indicates the improvement in the dependent variable the level of empathy on service quality ). Due to the increase in strategic flexibility we conclude that increasing the strategic flexibility by the value of one unit leads to an improvement in the level of sympathy in the service quality provided by the General Authority for Communications and Information Technology (32.6\%) of this unit. Followed by the effect after structural elasticity, the calculated value of $t$ (2.027) and the value of (beta) (0.306), which are statistically significant values at $(\alpha \leq 0.05)$. Furthermore, the value of B (0.303) indicates that the increase in the structural flexibility of the value of one unit leads to an improvement in the level of sympathy in the service quality provided by the General Authority for Communications and Information Technology $(30.3 \%)$ of this unit.

The results in the previous table indicate that the operational flexibility does not affect the level of sympathy for the service quality provided by the General Authority for Communications and Information Technology. The values of $(t)$ and (Beta) of this dimension haven't reached the specified level $(\alpha \leq 0.05)$. In light of the previous results, the fifth sub-hypothesis is rejected in part, as follows: There is a statistically significant positive effect at the level of $(\alpha \leq 0.05)$ for the strategic flexibility and structural flexibility on the level of sympathy in the service quality provided by the General Authority for Communications and Information Technology in the State of Kuwait. However, there is no significant effect at the level of $(\alpha \leq 0.05)$ for the operational flexibility at the level of sympathy in the service quality provided by the General Authority for Communications and Information Technology in the State of Kuwait.

\section{Conclution}

1. There is statistically significant positive effect organizational resilience (operational flexibility, structural flexibility) which has been demonstrated at the level of service quality provided by the General Telecommunications and Information Technology authority of the State of Kuwait.

2. There is existence of a statistically significant positive impact on the level of structural 
flexibility in the service quality provided by the General Authority for Communications and information technology in the State of Kuwait has been shown.

3. There is a positive and statistically significant impact of operational flexibility on the level of reliability in the service quality provided by the General Authority for Communications and information technology in the State of Kuwait has been shown.

4. There is a positive and statistically significant effect of operational flexibility has been demonstrated at the level of responsiveness in the service quality provided by the General Telecommunications and Information Technology authority in the State of Kuwait.

5. There is a statistically significant positive effect of operational flexibility and structural flexibility has been demonstrated in the level of confidence and security in the service quality provided by the General Telecommunications and Information Technology authority in the State of Kuwait.

6. There is an existence of a positive and statistically significant impact on strategic flexibility and structural resilience has been demonstrated by the level of sympathy for the service quality provided by the general Authority for information and communications technology in the State of Kuwait.

7. The study demonstrated that organizational flexibility helps to increase the overall value of service proposals delivered to clients, and organizational flexibility helps to increase the satisfaction of the service receiver audience

\section{Recommendations}

Depending on the findings of the study, the following recommendations were suggested:

11-1.It's important for the General Authority for Communications and Information Technology in the State of Kuwait to work on improvement of strategic flexibility through the adoption of strategic methods contribute to improving capabilities and create a competitive advantage, and be away from the traditional ways to make future strategic plans ,the Commission has to adopt a strategic plan that will enable it to deal with the resources and assetsto enable them to invest in an optimal manner, and review the process of making the strategic decisions to contribute to develop basic technologies and to replace the basic cover with the least resources for providing the services.

11-2.There is a need for the General Authority for Communications and Information Technology in the State of Kuwait to improve operational flexibility by taking care to make changes in the early stages of activity. Suvh procedure helps to increase their capacity to adapt to the increasing volume of their operations, and the need to adopt flexibility by changing the number of employees or distributing work hours during times when the volume of activity is higher or lower than the normal rate of adaptation to this change in the volume of provided services. In addition, it's important to make a change in the type of work that used by the Commission without resorting to the use of the external labor market, by designing functions capable of Containment a wide range of tasks. 


\section{Acknowledgement}

For the General Authority for Communications and Information Technology in the State of Kuwait.

\section{References}

Al Fadel, M. W. (2015). Application of the Flexible Organization Concept in Public Universities in the Hashemite Kingdom of Jordan, Babel University Journal of Humanities, 2(23), 902-920.

Al-Anizi, S. A., \& Atwi, A. H. (2013). Department of Contradictions, (I 1), Baghdad: Memory for Publishing and Distribution.

Al-Bakri, T. (2010). Marketing Health Services, Amman: Dar Al Yazouri Scientific Publishing and Distribution.

Al-Saman, T. A., \& Jabbouri, M. (2016). Information Technology Governance and Its Role in Improving Service Quality: Case Study in the General Directorate of Electricity Production, Salah al-Din, Arab Journal of Management, 1(36), 125-141.

Al-Sarayreh, A., \& Naila, M. Al-H. (2016). The Impact of Human Resources Auditing on the Application of Governance in the Banking Sector in Jordan. Macrothink Journal,of Human Resource Mangement . Canada, No5.

Al-Sarayreh, A., \& Ruwaida, G. (2010). The Role of Human Resource Management in Organizational Creativity as Seen by Jordan Telecom Company Workers: A Case Study, Jordanian Journal of Business Administration, 6(7).

Al-Tit, A. A. (2016). The Mediating Role of Knowledge Management and the Mode Part of Organizational Culture between HRM Practices and Organizational Performance.International Busniess Research journal, 9(1). https://doi.org/10.5539/ibr.v9n1p43

Altman, E. H. (1998). Service Quality \& Customer Satisfaction Do Matter, American Libraries, 1(29).

Al-Wadi, M., Samhan, H., \& Nazzal, A. (2010). Quality of Islamic Banking Services, 1, Amman: Dar Al Safa Publishing and Distribution.

Bou, A. S. (2010). Measurement of Service quality: An Empirical Study on Algeria Post, Journal of Economic Sciences and Management Sciences, 5(10), 89-109.

Boyabatli, O., \& Leng, T. (2017). The Interaction between Operational Flexibility and Financial Flexibility. Research Collection Lee Kong Chian School of Business, Foundations and Trends in Technology, Information and Operations Management journal, 11(2), 13-31. https://doi.org/10.1561/0200000077

Cornescu, E. A. (2012). Flexible Organization, Global Business and Management Research: An International Journal, 4(3 \& 4), 277-285. 


\section{Macrothink}

International Journal of Human Resource Studies

ISSN 2162-3058

2019, Vol. 9, No. 3

Dulaimi, R. M. (2005). Re-engineering of Hospital Work on Quality of Health Service (Master Thesis), Faculty of Business and Administration, University of Mosul.

Hartwig, K., \& Billert, M. S. (2018). Measuring Service Quality: A Systematic Literature Review. In: European Conference on Information Systems (ECIS). Portsmouth, UK.

Heng, I. (2010). Organizational flexibility management in construction, PHD dissertation, national university of Singapore.

Idrees, W. M., \& Al-Ghalebi, T. M. (2013). Examining the Effect of Strategic Flexibility as a Mediator on the Relationship of Environmental Uncertainty in Strategic Decision Making: A Pilot Study in Jordanian Human Medicines Manufacturers, Arab Journal of Management, 33-1, 105-134.

Li, Y., Liu, Y., Duan, Y., \& Li, M., (2008). Entrepreneurial orientation, strategic flexibilities and indigenous firm innovation in transitional China, International Journal of Technology Management, 1-2(41), 223-245. https://doi.org/10.1504/IJTM.2008.015993

Madhani, P. (2013). Organizational Flexibility: Real Option Approach, SCMS Journal of Indian Management, quarterly journal, 2(3), 43-54.

Mohammed, A. K. (2011). Role of the dimensions of the quality of Islamic banking service in achieving customer satisfaction: Analytical field study of the Islamic Bank in Nineveh Province, Tikrit Journal for Administrative and Economic Sciences, 23(7), 31-47.

Shalender, K. (2015). Organizational Flexibility for Superior Value Proposition: Implications for Service Industry, International Journal of Economics and Management Sciences, 4(6), 265-268. https://doi.org/10.4172/2162-6359.1000256

Weerdt, N. (2009). Organizational Flexibility for Hypercompetitive Markets: Empirical Evidence of the Composition and Context Specificity of Dynamic Capabilities and Organization Design Parameters, ERIM (PhD) Series in Research in Management, 1(7), ISBN 978-90-5892-215-1.

Weerdt, N., \& Volberda, H., Verwaal, E. (2012). Organizing for Flexibility: Addressing Dynamic Capabilities and Organization Design, Research Gate, Information and Organization Design Series, 105-125. https://doi.org/10.1007/978-1-4614-1284-7_7

Zaidi, N. J., \& Al-Khazraji, Q. I. (2016). The Role of Regulatory Flexibility and its Implications in Responding to Achieve Higher Performance Requirements - Field Research in the Municipal Sector, Journal of Economic and Administrative Sciences, 22(94), 50-83.

\section{Copyright Disclaimer}

Copyright for this article is retained by the author(s), with first publication rights granted to the journal.

This is an open-access article distributed under the terms and conditions of the Creative Commons Attribution license (http://creativecommons.org/licenses/by/4.0/). 